1 Antibody longevity and cross-neutralizing activity following SARS-CoV-2 wave 1 and

\title{
B.1.1.7 infections
}

4 Liane Dupont, ${ }^{1 *}$ Luke B. Snell, ${ }^{2 *}$ Carl Graham, ${ }^{1 *}$ Jeffrey Seow, ${ }^{1}$ Blair Merrick, ${ }^{2}$ Thomas

5 Lechmere, ${ }^{1}$ Sadie R. Hallett, ${ }^{1}$ Themoula Charalampous, ${ }^{2}$ Adela Alcolea-Medina, ${ }^{2}$ Isabella

6 Huettner, ${ }^{1}$ Thomas J. A. Maguire, ${ }^{1}$ Sam Acors, ${ }^{1}$ Nathalia Almeida, ${ }^{1}$ Daniel Cox, ${ }^{1}$ Ruth E.

7 Dickenson, ${ }^{1}$ Rui Pedro Galao, ${ }^{1}$ Jose M. Jimenez-Guardeño, ${ }^{1}$ Neophytos Kouphou, ${ }^{1}$ Marie 8 Jose Lista, ${ }^{1}$ Suzanne Pickering, ${ }^{1}$ Ana Maria Ortega-Prieto, ${ }^{1}$ Harry Wilson, ${ }^{1}$ Helena 9 Winstone, ${ }^{1}$ Cassandra Fairhead, ${ }^{2}$ Jia Su, ${ }^{2}$ Gaia Nebbia, ${ }^{2}$ Rahul Batra, ${ }^{2}$ Stuart Neil, ${ }^{1}$ Manu

10 Shankar-Hari, ${ }^{1}$ Jonathan D. Edgeworth, ${ }^{2}$ Michael H. Malim, ${ }^{1}$ Katie J. Doores ${ }^{1} \#$

$12{ }^{1}$ Department of Infectious Diseases, School of Immunology \& Microbial Sciences, King's

13 College London, London, UK.

$14{ }^{2}$ Centre for Clinical Infection and Diagnostics Research, Department of Infectious Diseases,

15 Guy's and St Thomas' NHS Foundation Trust, London, UK.

16

17 * These authors contributed equally

18 \# To whom correspondence should be addressed: katie.doores@kcl.ac.uk

19 
medRxiv preprint doi: https://doi.org/10.1101/2021.06.07.21258351; this version posted June 8, 2021. The copyright holder for this preprint (which was not certified by peer review) is the author/funder, who has granted medRxiv a license to display the preprint in perpetuity.

It is made available under a CC-BY-NC-ND 4.0 International license .

21 Abstract:

22 As SARS-CoV-2 variants continue to emerge globally, a major challenge for COVID-19

23 vaccination is the generation of a durable antibody response with cross-neutralizing activity

24 against both current and newly emerging viral variants. Cross-neutralizing activity against

25 major variants of concern (B.1.1.7, P.1 and B.1.351) has been observed following

26 vaccination, albeit at a reduced potency, but whether vaccines based on the Spike

27 glycoprotein of these viral variants will produce a superior cross-neutralizing antibody

28 response has not been fully investigated. Here, we used sera from individuals infected in

29 wave 1 in the UK to study the long-term cross-neutralization up to 10 months post onset of

30 symptoms (POS), as well as sera from individuals infected with the B.1.1.7 variant to

31 compare cross-neutralizing activity profiles. We show that neutralizing antibodies with cross-

32 neutralizing activity can be detected from wave 1 up to 10 months POS. Although

33 neutralization of B.1.1.7 and B.1.351 is lower, the difference in neutralization potency

34 decreases at later timepoints suggesting continued antibody maturation and improved

35 tolerance to Spike mutations. Interestingly, we found that B.1.1.7 infection also generates a

36 cross-neutralizing antibody response, which, although still less potent against B.1.351, can

37 neutralize parental wave 1 virus to a similar degree as B.1.1.7. These findings have

38 implications for the optimization of vaccines that protect against newly emerging viral

39 variants.

40 
medRxiv preprint doi: https://doi.org/10.1101/2021.06.07.21258351; this version posted June 8, 2021. The copyright holder for this preprint (which was not certified by peer review) is the author/funder, who has granted medRxiv a license to display the preprint in perpetuity.

It is made available under a CC-BY-NC-ND 4.0 International license .

\section{Introduction:}

Neutralizing antibodies against the Spike glycoprotein of severe acute respiratory syndrome coronavirus 2 (SARS-CoV-2) are important in protection from re-infection and/or severe disease..$^{1-6}$ Vaccines that protect against COVID-19 have been rapidly developed, and an important component of these vaccines is the elicitation of neutralizing antibodies that bind the SARS-CoV-2 Spike protein, in particular the receptor binding domain (RBD). A major challenge in controlling the COVID-19 pandemic will be elicitation of a durable neutralizing antibody response that also provides protection against SARS-CoV-2 emerging variants. Whilst the kinetics and correlates of the neutralizing antibody response have been extensively studied in the early phase following SARS-CoV-2 infection, ${ }^{7-12}$ information on durability and long-term cross-reactivity of the antibody response against SARS-CoV-2 following infection and/or vaccination is limited due to its recent emergence in the human population and large-scale COVID-19 vaccination only being initiated in December 2020.

We have previously studied the antibody response in SARS-CoV-2 infected healthcare workers and hospitalized individuals in the first 3 months following infection using longitudinal samples ${ }^{8}$. We showed that the humoral immune response was typical of that following an acute viral infection where the sera neutralizing activity peaked around 3-5 weeks post onset of symptoms (POS) and then declined as the short-lived antibodysecreting cells die. ${ }^{3}$ However, it remained to be seen whether the neutralizing antibody response would continue to decline after the first 3 months POS or reach a steady state. In the absence of current long-term COVID-19 vaccine follow-up, knowledge of the longevity of the neutralizing antibody response acquired through natural infection in wave 1 of the COVID-19 pandemic at late timepoints (up to 10 months POS) may provide important indicators for the durability of vaccine induced humoral immunity.

SARS-CoV-2 variants encoding mutations in Spike have been identified and include B.1.1.7 (initially reported in the UK), ${ }^{13}$ P.1 (first reported in Brazil) and B.1.351 (first reported in South Africa $)^{14}$ which have been associated with more efficient transmission. ${ }^{15-17}$ Mutations of particular concern for vaccine immunity are those present in the receptor 
medRxiv preprint doi: https://doi.org/10.1101/2021.06.07.21258351; this version posted June 8, 2021. The copyright holder for this preprint (which was not certified by peer review) is the author/funder, who has granted medRxiv a license to display the preprint in perpetuity.

It is made available under a CC-BY-NC-ND 4.0 International license.

70 binding domain (RBD) of Spike which is a dominant target for the neutralizing antibody

71 response. $^{18}$ Despite B.1.1.7, P.1 and B.1.351 showing increased resistance to neutralization

72 by convalescent and vaccinee sera collected at the peak of the antibody response, ${ }^{19-29}$

73 cross-neutralizing activity has been observed, albeit at a lower magnitude. In contrast,

74 complete loss of neutralization has been observed for some monoclonal antibodies targeting

75 specific epitopes on either the $N$-terminal domain (NTD) or RBD of Spike. ${ }^{20,22,24,25,30}$

76 Combined, these studies indicate that Spike mutations may be arising in part due to the

77 selective pressure of neutralizing antibodies in convalescent plasma ${ }^{31-33}$. To counter such

78 mutations and their attendant antigenic changes, vaccines using the Spike proteins from

79 these variants of concern (VOCs) are under investigation. ${ }^{34-37}$ Whether the variant Spikes

80 will elicit a robust neutralizing response with superior cross-neutralizing activity against

81 parental strains and newly emerging variants has not been extensively studied. ${ }^{26,38,39}$ Natural

82 infection provides an important opportunity to compare the neutralizing antibody titres and

83 cross-neutralizing activity generated from individuals exposed to different Spike variants and

84 will give insights into how mutations in Spike impact immunogenicity, thereby informing the

85 design of second generation vaccine candidates based on VOCs.

86 In this study we set out to investigate; i) the longevity of the neutralizing and cross-

87 neutralizing antibody response against viral variants from wave 1 infections up to 10 months

88 POS, ii) the immunogenicity of the B.1.1.7 Spike in natural infection, and iii) cross-reactivity

89 of sera following B.1.1.7 infection. We collected sera between 145-305 days POS from

90 individuals infected in wave 1 that were in our original hospitalized patient and healthcare

91 worker cohorts, as well as sera from individuals with a confirmed B.1.1.7 infection between

92 6-73 days POS. Following the initial decline phase, neutralization titres reached a steady

93 state and could be detected in the majority of sera collected up to 10 months POS. We

94 observed cross-neutralization of wild-type (Wuhan strain, WT), B.1.1.7, P.1 and B.1.351

95 pseudotyped viral particles for both wave 1 and B.1.1.7 sera. The B.1.351 variant showed

96 the greatest reduction in neutralization sensitivity although the fold change in neutralization

97 compared to WT diminished at later times POS. Importantly, B.1.1.7 infection generated 
medRxiv preprint doi: https://doi.org/10.1101/2021.06.07.21258351; this version posted June 8, 2021. The copyright holder for this preprint (which was not certified by peer review) is the author/funder, who has granted medRxiv a license to display the preprint in perpetuity.

It is made available under a CC-BY-NC-ND 4.0 International license .

98 neutralizing antibody titres against B.1.1.7 and WT virus that were more similar to each other

99 than was observed for wave 1 sera, indicating maintained efficacy against previously

100 circulating strains. Overall, these findings provide important insights into long-term immunity

101 to SARS-CoV-2 and have implications for optimization of vaccines that protect against newly

102 emerging viral variants.

103

104 Results:

105 IgG to Spike persist for up to 10 months post onset of symptoms

106 Our initial study measured antibody responses in sera up to 3 months POS in 107 hospitalized patients and healthcare workers experiencing a range of COVID-19 severity,

108 from asymptomatic infection to requiring ECMO. ${ }^{8}$ Additional serum samples were collected

109 from a subset of these individuals at time points $>100$ days POS when they returned to 110 hospital as part of their routine clinical care, as well as from HCW still working at St Thomas'

111 Hospital. No participants had received the COVID-19 vaccine at serum collection. In total, 64

112 sera were collected from 38 individuals, including 16 sera collected between 145-175 days

113 POS (TP3), 29 collected between 180-217 days (TP4), and 19 collected between 257-305

114 days POS (TP5). We first determined the presence of IgM and IgG against Spike, RBD and

$115 \mathrm{~N}$ in patient sera collected at $>100$ days POS (Figure 1A-F). OD values were measured for

116 sera diluted at 1:50. Although the $\lg M$ response decreased to low levels against $S, R B D$ and

$117 \mathrm{~N}$ at later timepoints, IgM was still detected against all three antigens in some individuals.

118 The lgG response also decreased over time to some extent for most individuals but

119 remained detectable at timepoints up to $\sim 300$ days POS. Those with IgG OD values near to

120 baseline spanned across all severity groups.

121 We previously used pre-COVID-19 control sera to set a threshold OD value of 4-fold

122 above background as a cut-off for SARS-CoV-2 seropositivity. ${ }^{40}$ Using this cut-off, 5/45

$123(11.1 \%)$ and $3 / 19(6.7 \%)$ of individuals had IgG below the cut-off against all three antigens

124 (S, RBD and N) between TP3+4 and TP5, respectively. The lowest seroreactivity was

125 observed against RBD at timepoints $>145$ days POS. IgG to $N$ has been used as an 
medRxiv preprint doi: https://doi.org/10.1101/2021.06.07.21258351; this version posted June 8, 2021. The copyright holder for this preprint (which was not certified by peer review) is the author/funder, who has granted medRxiv a license to display the preprint in perpetuity.

It is made available under a CC-BY-NC-ND 4.0 International license .

126 indicator of previous SARS-CoV-2 infection when studying COVID-19 vaccine

127 responses. ${ }^{41,42}$ However, at $>145$ days POS, 17/64 (26.6\%) of sera had an OD value against

$128 \mathrm{~N}$ that was below this threshold and suggests a complementary or alternative SARS-CoV-2

129 antigen is needed to improve the determination of previous virus exposure in the context of

130 vaccination for individuals infected $>6$ months previously.

131

132 Neutralizing antibody responses are maintained up 10 months post onset of 133 symptoms

134 The longevity of the neutralizing activity in patient sera was measured using HIV-1

135 based virus particles pseudotyped with SARS-CoV-2 Wuhan Spike (referred to as wild-type,

136 WT) (Figure 1G and Figure S1A). Our previous study had shown a decline in neutralizing

137 antibody titre in the first 3 months following SARS-CoV-2 infection but whether the titre

138 would reach a steady level was not determined. The neutralization potency of matched

139 Iongitudinal sera collected at timepoints up to 305 days POS revealed that the rate of decline

140 in neutralization activity slowed in the subsequent 4-7-month period and neutralizing activity

141 could readily be detected in 18/19 of sera tested at TP5 with a geometric mean titre (GMT)

142 of 640 . ELISA OD values for $S \lg G$, RBD $\lg G$ and $N \lg G$ correlated well with $I_{50}$ of

143 neutralization (Figure S1B). A cross-sectional analysis of all the wave 1 sera showed the

144 GMT at TP3, TP4, and TP5 decreased from 1,199 to 635 and 640, respectively. The

145 percentage of donors displaying potent neutralization $\left(\operatorname{ID}_{50}>2,000\right)$ was $48.2 \%$ at peak

146 neutralization (as previously determined in Seow et $\mathrm{al}^{8}$ ) and this decreased to $27.8 \%, 13.8 \%$

147 and $15.8 \%$ at TP3, TP4 and TP5, respectively (Figure S1C).

148 We had previously observed that individuals experiencing the most severe disease

149 had higher peak neutralization titres. ${ }^{8}$ In concordance with this, we observed higher mean

150 peak $I_{50}$ values for those with most severe disease, as well as higher titres at TP3, TP4

151 and TP5, although this trend was not always statistically significant (Figure 1H). A wider

152 heterogeneity in the magnitude of the neutralizing antibody response in the $0-3$ severity

153 group was seen at all time points studied compared to the 4-5 severity group. 
medRxiv preprint doi: https://doi.org/10.1101/2021.06.07.21258351; this version posted June 8, 2021. The copyright holder for this preprint (which was not certified by peer review) is the author/funder, who has granted medRxiv a license to display the preprint in perpetuity.

It is made available under a CC-BY-NC-ND 4.0 International license .

154 Overall, neutralizing antibody response following SARS-CoV-2 infection can persist

155 for as long as 10 months POS.

156

157 Sera from individuals infected during UK wave 1 shows cross-neutralizing activity 158 against SARS-CoV-2 VOCs

159 Initially, longitudinal sera collected from 14 individuals between days 6 and 305 POS

160 were used to compare the magnitude and kinetics of neutralizing activity against the SARS-

161 CoV-2 variants; B.1.1.7, P.1 and B.1.351 (Figure 2A). The kinetics of neutralizing activity in 162 sera were similar against all four variants and a peak in neutralization was observed around 163 3-5 weeks POS followed by decline to a steady level of neutralization (Figure 2B).

164 Having observed similar kinetics in the neutralization of VOCs, we focused further on

165 the extent of cross-neutralizing activity of wave 1 sera collected at later time-points (145-305

166 days POS). Neutralization titres $\left(\mathrm{ID}_{50}\right)$ against the four variants were measured $(\mathrm{n}=66)$ and

167 the fold change in $\mathrm{ID}_{50}$ compared to wild-type for each variant was compared within five time 168 windows; acute (20-40 days POS), TP2 (55-100 days POS), TP3, TP4 and TP5 (Figure

169 2C). Neutralization potency against the P.1 variant was most similar to neutralization 170 potency against wild-type virus at all five time-points, with an average reduction in $I_{50}$ 171 ranging from 1.2-1.3 fold (Figure 2D). In contrast, and similar to previous reports, ${ }^{19-27}$ both

172 B.1.1.7 and B.1.351 were more resistant to neutralization at all time points, with the greatest 173 decrease in neutralization observed for B.1.351. At later timepoints, the mean fold change in 174 neutralization $I D_{50}$ for both the B.1.1.7 and B.1.351 variants compared to wild-type $I D_{50}$ was 175 decreased in magnitude (Figure 2D), suggesting continued antibody maturation and 176 improved tolerance to Spike mutations. For example, the average fold reduction in $\mathrm{ID}_{50}$ 177 against B.1.351 was 8.9-fold in the acute phase and this decreased to 2.9-fold at TP5. 178 Individuals experiencing more severe COVID-19 (severity 4-5) consistently showed higher 179 neutralization titres against the VOCs compared to those experiencing milder disease 180 (severity 0 -3) (Figure 2E). 
medRxiv preprint doi: https://doi.org/10.1101/2021.06.07.21258351; this version posted June 8, 2021. The copyright holder for this preprint (which was not certified by peer review) is the author/funder, who has granted medRxiv a license to display the preprint in perpetuity.

It is made available under a CC-BY-NC-ND 4.0 International license .

181 Overall, wave 1 sera showed neutralizing activity against P.1, B.1.1.7 and B.1.351,

182 albeit at a lower potency for B.1.1.7 and B.1.351.

183

184 Sera from individuals infected with the B.1.1.7 variant retain neutralizing activity 185 against early variants

186 During the UK second wave of COVID-19 in December 2020 - February 2021, the 187 predominant variant infecting patients at St Thomas Hospital in London was B.1.1.7. Whole 188 genome sequencing was used to confirm infection with this lineage and corresponding sera 189 samples $(\mathrm{n}=81)$ were collected from 39 individuals between 4- and 79- days POS at 190 multiple time-points where possible. Homologous neutralization and cross-neutralizing 191 activity were measured against wild-type, P.1 and B.1.351 pseudotyped particles (Figure 3 192 and Figure S2).

193 Sera from individuals infected with B.1.1.7 showed potent homologous neutralization

194 (Figure 3A). Analysis of both serially collected samples (Figure 3B) and cross-sectional 195 samples (Figure 3A) showed that the neutralization of the B.1.1.7 variant followed a similar 196 kinetics with highest neutralization titres being detected around 3-5 weeks POS. For sera 197 collected near the peak of the antibody response (21-35 days POS), more potent 198 homologous neutralization was observed for wave 1 than B.1.1.7 sera (Figure 3C), i.e. a 199 higher GMT ID 50 was observed for wave 1 sera against WT pseudotyped particles compared 200 to B.1.1.7 sera against B.1.1.7 pseudotyped particles. This may be indicative of a higher 201 immunogenicity of the WT Spike compared to the B.1.1.7 Spike, or of increased 202 administration of immunosuppressive drugs, e.g. Dexamethasone during the $2^{\text {nd }}$ wave of 203 COVID-19 in the UK.

204 The majority of B.1.1.7 sera showed cross-neutralizing activity against the other 205 VOCs (Figure S2C). Similar to wave 1 sera, the lowest cross-neutralization was observed 206 against B.1.351 which exhibited an average 5.7-fold reduction in neutralizing activity 207 compared to neutralization against B.1.1.7 across all samples studied. Neutralization of P.1 208 and WT were reduced by an average 1.2- and 1.7-fold compared the B.1.1.7. To enable a 
medRxiv preprint doi: https://doi.org/10.1101/2021.06.07.21258351; this version posted June 8, 2021. The copyright holder for this preprint (which was not certified by peer review) is the author/funder, who has granted medRxiv a license to display the preprint in perpetuity.

It is made available under a CC-BY-NC-ND 4.0 International license .

209 fair comparison of cross-neutralizing activity generated by infection with WT or B.1.1.7 virus,

210 neutralization potency against the four viruses was compared for all sera collected between

211 days 10 - 60 POS (Figure 3D). Both B.1.1.7 sera (Figure 3D) and wave 1 sera (Figure 3E)

212 showed a reduction in neutralization of B.1.351 compared to homologous neutralization of

213 WT and B.1.1.7 pseudotypes (average 5.9- and 8.3-fold, respectively). Neutralization of P.1

214 by either wave 1 or B.1.1.7 sera was largely unchanged (1.3- and 1.2-fold changes,

215 respectively). However, in contrast to convalescent sera from wave 1 that had an average

216 3.3-fold reduction in B.1.1.7 neutralization, there was only an average 1.7-fold reduction in

217 WT neutralization by B.1.1.7 sera suggesting that neutralization is retained against earlier

218 lineage variants if infected with B.1.1.7.

219 As we had previously observed a correlate between disease severity and

220 neutralization titre for wave 1 sera (Figure 2E), we similarly compared the geometric mean

221 titres for those with 0-3 and 4-5 disease severity for all B.1.1.7 serum samples. In contrast to

222 wave 1 sera, the sera from B.1.1.7 infected individuals experiencing 4-5 disease severity did

223 not display such an enhanced neutralization potency compared to the less severe group

224 which may also reflect the increased administration of immunosuppressive drugs during

225 treatment (Figure 3F).

226 Overall, sera from individuals infected with the B.1.1.7 variant displayed potent cross-

227 neutralizing activity.

\section{Sera from individuals infected with B.1.351 displays potent homologous}

\section{0 neutralization}

Lastly, sera were collected from three individuals receiving treatment for COVID-19

232 at St Thomas' hospital who were confirmed to have been infected with the B.1.351 variant.

233 All experienced severity 4 illness. Neutralization against the four variants was measured.

234 Robust neutralization of B.1.351 was observed. Although only a very small sample size, in

235 contrast to wave 1 and B.1.1.7 sera, neutralization of B.1.351 by these sera appeared more

236 comparable to the other three variants (Figure 3G). 
medRxiv preprint doi: https://doi.org/10.1101/2021.06.07.21258351; this version posted June 8, 2021. The copyright holder for this preprint (which was not certified by peer review) is the author/funder, who has granted medRxiv a license to display the preprint in perpetuity.

It is made available under a CC-BY-NC-ND 4.0 International license .

238 Discussion

239 With the recent entry of SARS-CoV-2 into the human population, there is limited

240 information on the longevity of the antibody response following natural infection or COVID-

24119 vaccination. Initial concerns were that the SARS-CoV-2 antibody response might mimic

242 that of other human endemic coronaviruses, such as $229 \mathrm{E}$, where antibody responses are

243 short-lived and re-infections occur. ${ }^{43,44}$ However, the data presented here supports other

244 recent studies ${ }^{9,45-52}$ showing that although neutralizing antibody titres decline from the initial

245 peak response, robust neutralizing activity can still be detected in a large proportion of

246 convalescent sera at up to 10 months POS. As $\lg M$ has been shown to facilitate

247 neutralization, ${ }^{8,53}$ the initial decline in neutralization is likely in part due to the reduction in

248 circulating serum IgM observed, as well as the death of short-lived antibody-secreting cells,

249 with the sustained neutralizing activity therefore arising from long-lived plasma cells

250 producing spike-reactive $\lg$. $^{3,51,54}$ We observed a more notable decline in $\lg$ to $\mathrm{N}$

251 compared to $\lg$ to Spike which has also been observed by others ${ }^{51}$ and is particularly

252 relevant when considering using IgG to $\mathrm{N}$ to determine prior SARS-CoV-2 infection in

253 COVID-19 vaccination studies. Further assessment of the longevity of the neutralizing

254 antibody response arising from SARS-CoV-2 natural infection will become increasingly

255 difficult as more of the global population receive a COVID-19 vaccine.

256 Although sustained neutralization against the infecting SARS-CoV-2 variant is

257 important, efficacious cross-neutralizing activity is essential for long-term protection against

258 newly emerging variants. As RBD has been identified as a major target for the neutralizing

259 antibody response to SARS-CoV-2, mutations K417T/N, E484K and N501Y are of particular

260 concern for immune evasion and have been shown to lead to resistance to some RBD

261 specific mAbs. ${ }^{25,55-58}$ Additionally, mutations in NTD can also lead to neutralization resistance

262 against NTD-specific mAbs. ${ }^{20,25,59}$ In this present study, the largest decrease in neutralization

263 potency for both wave 1 (overall average 4.8-fold) and B.1.1.7 sera (overall average 5.7-

264 fold) was observed against B.1.351 which encodes RBD mutations K417N, E484K and 
medRxiv preprint doi: https://doi.org/10.1101/2021.06.07.21258351; this version posted June 8, 2021. The copyright holder for this preprint (which was not certified by peer review) is the author/funder, who has granted medRxiv a license to display the preprint in perpetuity.

It is made available under a CC-BY-NC-ND 4.0 International license .

265 N501Y. Despite P.1 encoding similar RBD mutations K417T, E484K and N501Y, only a very

266 minor decrease in neutralization potency was observed. As these two VOCs also encode a

267 different pattern of NTD and S2 mutations, these data indicate that the RBD is not the only

268 antigenic region responsible for reduced neutralization potency and suggests that

269 assessment of mutational profiles throughout Spike will be important when considering

270 immune evasion by emerging viral variants. ${ }^{24}$

271 Despite the reduction in neutralization potency seen in wave 1 sera against B.1.1.7

272 and B.1.351, GMT of 3,331 and 1,303 (Figures $\mathbf{2 C}$ and $\mathbf{S 2 C}$ ), respectively, were still

273 observed at the neutralization peak, and neutralization $\left(\mathrm{ID}_{50}>25\right)$ was detected in $17 / 19$ and

274 18/19 of individuals at 257-305 days against B.1.1.7 and B.1.351. These data highlight how

275 the polyclonal nature of convalescent sera enables antiviral functionality against mutant

276 Spikes present in emerging viral variants. Whether the neutralizing antibody titres reported

277 here will be sufficient to protect from infection and/or severe disease is not fully understood. ${ }^{3-}$

2786,60 Several studies have reported a lower vaccine efficacy in locations where B.1.351 is

279 prevalent $^{61,62}$ whereas protection against B.1.1.7 infection has been reported in Israel

280 following vaccination with BNT162b2 ${ }^{63}$ and following AZD1222 in the UK. ${ }^{64}$ Interestingly, the

281 differential neutralization of B.1.351 and B.1.1.7 compared to WT virus decreased at later

282 timepoints for wave 1 sera, suggesting that antibodies present at later timepoints are better

283 able to tolerate Spike mutations. Indeed, a study by Gaebler et al showed that SARS-CoV-2

284 monoclonal antibodies isolated 6-months POS had more somatic hypermutation and

285 displayed a greater resistance to RBD mutations. ${ }^{55}$ These findings suggest that COVID-19

286 vaccine boosting may further increase neutralization breadth and protection against newly

287 emerging SARS-CoV-2 VOCs.

288 Spikes from VOCs are being investigated as second-generation vaccine candidates

289 to tackle the challenges associated with protection against SARS-CoV-2 emerging

290 variants ${ }^{34-37}$ and therefore, studying the immune response to Spike variants in natural

291 infection can provide insight into differential Spike immunogenicity. We show that infection

292 with B.1.1.7 elicits a robust neutralizing antibody response against B.1.1.7, P.1 and WT 
medRxiv preprint doi: https://doi.org/10.1101/2021.06.07.21258351; this version posted June 8, 2021. The copyright holder for this preprint (which was not certified by peer review) is the author/funder, who has granted medRxiv a license to display the preprint in perpetuity.

It is made available under a CC-BY-NC-ND 4.0 International license .

293 variants. For the majority of donors, the $\mathrm{ID}_{50} \mathrm{~s}$ against B.1.1.7 and WT were very similar

294 indicating that neutralizing antibodies arising from infection with B.1.1.7 are able to maintain

295 efficacy against previously dominant SARS-CoV-2 variants. These findings contrast with

296 Faulkner et al who observed a decreased level of cross-neutralization in B.1.1.7 infected

297 individuals. ${ }^{38}$ However, Faulkner et al used sera collected at around 11 days POS and, as

298 discussed above, cross-neutralizing activity likely develops over time. Here we show that,

299 similar to wave 1 sera, neutralization of B.1.351 by B.1.1.7 sera was reduced compared

300 neutralization of B.1.1.7 and suggests the shared N501Y mutation is not sufficient to

301 overcome the B.1.351 neutralization resistance, an independent SARS-CoV-2 lineage. A

302 study by Moyo-Gwete et al demonstrated that individuals infected with B.1.351 elicited

303 potent neutralizing antibodies against B.1.351 and P.1 but reduced titres against Wuhan-

304 D614G variant. ${ }^{39}$ Cele et al showed that B.1.351 infection generated better cross-

305 neutralizing activity against earlier viral variants. ${ }^{26}$ Although a small sample size, our data

306 broadly support these observations and further demonstrate that B.1.351 infection elicits a

307 robust homologous neutralizing antibody response that also cross-neutralizes other VOCs.

308 Previous studies of wave 1 sera comparing antibody responses in individuals

309 experiencing different disease severities has shown that higher neutralization titres are

310 typically observed in those experiencing more severe disease.$^{8,21,65-67}$ Here we further show

311 that the difference in neutralization potency decreases at later timepoints. Indeed, Vanshylla

312 et al observed a more rapid initial decline in neutralizing antibody titres in those who

313 experience severe disease.$^{50}$ A similar analysis conducted with sera from B.1.1.7 infected

314 individuals revealed more similar neutralizing antibody responses between the two severity

315 groups. Whether this is related to improved disease management and increased use of

316 immunosuppressive drugs during the UK second wave infections or is intrinsic to the B.1.1.7

317 Spike would need to be investigated further.

318 In summary, using convalescent sera from individuals infected in wave 1 or

319 individuals infected with B.1.1.7, we show that cross-neutralizing antibodies are detected up

320 to 10 months POS in some individuals and that infection with B.1.1.7 generates a cross- 
medRxiv preprint doi: https://doi.org/10.1101/2021.06.07.21258351; this version posted June 8, 2021. The copyright holder for this preprint (which was not certified by peer review) is the author/funder, who has granted medRxiv a license to display the preprint in perpetuity. It is made available under a CC-BY-NC-ND 4.0 International license.

321 neutralizing antibody response that is effective against the parental virus. These findings

322 have implications for optimization of COVID-19 vaccines effective at eliciting a cross-

323 neutralizing antibody response that protects against SARS-CoV-2 viral variants.

324 
medRxiv preprint doi: https://doi.org/10.1101/2021.06.07.21258351; this version posted June 8, 2021. The copyright holder for this preprint (which was not certified by peer review) is the author/funder, who has granted medRxiv a license to display the preprint in perpetuity.

It is made available under a CC-BY-NC-ND 4.0 International license .

\section{Methods:}

326 Patient samples. Collection of surplus serum samples was approved by South Central REC 327 20/SC/0310. SARS-CoV-2 cases were diagnosed by RT-PCR of respiratory samples at St

328 Thomas' Hospital, London. 894 serum samples from 585 individuals were saved between 04 329 January 2020 and 12 March 2021. Samples obtained ranged from 8 days prior up to 319 330 days POS. Cases were linked to corresponding genome sequencing of viral isolates from

331 nose and throat swabs. Some sera were previously studied in Seow et aß as stated in the 332 manuscript.

334 Plasmids. The wild-type ${ }^{8}$ and B.1.1.7 ${ }^{20,21}$ Spike plasmids were described previously. B.1.1.7 335 mutations introduced were $\Delta \mathrm{H} 69 / \mathrm{V} 70, \Delta \mathrm{Y} 144, \mathrm{~N} 501 \mathrm{Y}, \mathrm{A} 570 \mathrm{D}, \mathrm{D} 614 \mathrm{G}, \mathrm{P} 681 \mathrm{H}, \mathrm{T} 716 \mathrm{I}$, 336 S982A, D1118H. Spikes encoding the variants B.1.351 and P.1 were synthesized (Genewiz, 337 USA) and cloned into pcDNA3.1. B.1.351 mutations introduced were L18F, D80A, D215G, 338 Delta242-244, R246I, K417N, E484K, N501Y, D614G, A701V. P.1 mutations introduced 339 were L18F, T20N, P26S, D138Y, R190S, K417T, E484K, N501Y, D614G, H655Y, T1027I, $340 \quad \mathrm{~V} 1176 \mathrm{~F}$.

342 COVID-19 severity classification. The score, ranging from 0 to 5 , was devised 343 to mitigate underestimating disease severity in patients not for escalation above level one 344 (ward-based) care. Patients diagnosed with COVID-19 were classified as follows: (0) 345 Asymptomatic or no requirement for supplemental oxygen; (1) Requirement for 346 supplemental oxygen (fraction of inspired oxygen $(F \mathrm{FO} 2)<0.4)$ for at least $12 \mathrm{~h}$; (2)

347 Requirement for supplemental oxygen $(\mathrm{FiO} 2 \geq 0.4)$ for at least $12 \mathrm{~h}$; (3) Requirement for 348 non-invasive ventilation/continuous positive airway not a candidate for escalation above 349 level one (ward-based) care; (4) Requirement for intubation and mechanical ventilation or 350 supplemental oxygen $(\mathrm{FiO} 2>0.8)$ and peripheral oxygen saturations $<90 \%$ (with no history 351 of type 2 respiratory failure $(\mathrm{T} 2 \mathrm{RF})$ ) or $<85 \%$ (with known T2RF) for at least $12 \mathrm{~h}$; (5) 352 Requirement for ECMO. 
medRxiv preprint doi: https://doi.org/10.1101/2021.06.07.21258351; this version posted June 8, 2021. The copyright holder for this preprint (which was not certified by peer review) is the author/funder, who has granted medRxiv a license to display the preprint in perpetuity.

It is made available under a CC-BY-NC-ND 4.0 International license .

354 Viral sequencing. Whole genome sequencing of residual nose-and-throat swab from

355 SARS-CoV-2 cases was performed using GridION (Oxford Nanopore Technology), using 356 version 3 of the ARTIC protocol and bioinformatics pipeline. ${ }^{68}$ From November 2020 all 357 samples from inpatients were assessed for sequencing. Samples were selected for 358 sequencing if the corrected CT value was 32 or below, or the Hologic Aptima assay was 359 above $1000 \mathrm{RLU}$, and if there was sufficient residual sample. Sequencing was performed 360 under COG-UK ethical approval. Lineage determination was performed using updated 361 versions of pangolin 2.0. ${ }^{69}$ Samples were regarded as successfully sequenced if over $50 \%$ 362 of the genome was recovered and if lineage assignment by pangolin was given with at least $36350 \%$ confidence.

365 ELISA binding to N, S and RBD. ELISAs were carried out as previously described. ${ }^{8,40}$ All sera were heat inactivated at $56^{\circ} \mathrm{C}$ for 30 min before use. High-binding ELISA plates

367 (Corning, 3690) were coated with antigen ( $\mathrm{N}$ protein, S glycoprotein or RBD) at $3 \mu \mathrm{g} / \mathrm{mL}$ (25

$368 \mu \mathrm{l}$ per well) in phosphate-buffered serum (PBS), either overnight at $4^{\circ} \mathrm{C}$ or for $2 \mathrm{~h}$ at $37^{\circ} \mathrm{C}$.

369 Wells were washed with PBS-T (PBS with $0.05 \%$ Tween-20) and then blocked with $100 \mu$ l of

$3705 \%$ milk in PBS-T for $1 \mathrm{~h}$ at room temperature. The wells were emptied, and serum diluted at

371 1:50 in milk was added and incubated for $2 \mathrm{~h}$ at room temperature. Wells were washed with

372 PBS-T. Secondary antibody was added and incubated for $1 \mathrm{~h}$ at room temperature. IgM was

373 detected using goat-anti-human-IgM-HRP (horseradish peroxidase) $(1: 1,000)$ (Sigma,

374 catalogue no. A6907) and IgG was detected using goat-anti-human-Fc-AP (alkaline

375 phosphatase) $(1: 1,000)$ (Jackson, catalogue no. 109-055-098). Wells were washed with

376 PBS-T and either AP substrate (Sigma) was added and read at $405 \mathrm{~nm}$ (AP) or one-step

377 3,3',5,5'-tetramethylbenzidine (TMB) substrate (Thermo Fisher Scientific) was added and

378 quenched with $0.5 \mathrm{M} \mathrm{H}_{2} \mathrm{SO}_{4}$ before reading at $450 \mathrm{~nm}$ (HRP). Control reagents included

379 CR3009 $(2 \mu \mathrm{g} / \mathrm{mL})$, CR3022 $(0.2 \mu \mathrm{g} / \mathrm{mL})$, negative control plasma (1:25 dilution), positive 
medRxiv preprint doi: https://doi.org/10.1101/2021.06.07.21258351; this version posted June 8, 2021. The copyright holder for this preprint (which was not certified by peer review) is the author/funder, who has granted medRxiv a license to display the preprint in perpetuity.

It is made available under a CC-BY-NC-ND 4.0 International license .

380 control plasma (1:50) and blank wells. ELISA measurements were performed in duplicate

381 and the mean of the two values was used.

382

383 SARS-CoV-2 pseudotyped virus particle preparation. Pseudotyped HIV virus

384 incorporating the SARS-CoV-2 Spike protein (either wild-type, B.1.1.7, P.1, B.1.351) was

385 produced in a $10 \mathrm{~cm}$ dish seeded the day prior with $5 \times 10^{6} \mathrm{HEK} 293 \mathrm{~T} / 17$ cells in $10 \mathrm{ml}$ of

386 complete Dulbecco's Modified Eagle's Medium (DMEM-C, 10\% FBS and 1\% Pen/Strep)

387 containing $10 \%$ ( $\mathrm{vol} / \mathrm{vol}$ ) foetal bovine serum (FBS), $100 \mathrm{lU} / \mathrm{ml}$ penicillin and $100 \mu \mathrm{g} / \mathrm{ml}$

388 streptomycin. Cells were transfected using $90 \mu \mathrm{g}$ of PEI-Max ( $1 \mathrm{mg} / \mathrm{mL}$, Polysciences) with:

$38915 \mu \mathrm{g}$ of HIV-luciferase plasmid, $10 \mu \mathrm{g}$ of HIV $8.91 \mathrm{gag} / \mathrm{pol}$ plasmid and $5 \mu \mathrm{g}$ of SARS-CoV-2

390 spike protein plasmid. $^{70,71}$ The supernatant was harvested 72 hours post-transfection.

391 Pseudotyped virus particles was filtered through a $0.45 \mu \mathrm{m}$ filter and stored at $-80^{\circ} \mathrm{C}$ until

392 required.

393

394 Neutralization assay with SARS-CoV-2 pseudotyped virus. Serial dilutions of serum

395 samples (heat inactivated at $56^{\circ} \mathrm{C}$ for 30 mins) were prepared with DMEM media (25uL)

396 (10\% FBS and 1\% Pen/Strep) and incubated with pseudotype virus (25uL) for 1-hour at

$39737^{\circ} \mathrm{C}$ in half-area 96 -well plates. Next, Hela cells stably expressing the ACE2 receptor were

398 added $(10,000$ cells $/ 25 \mu \mathrm{L}$ per well) and the plates were left for 72 hours. Infection level was

399 assessed in lysed cells with the Bright-Glo luciferase kit (Promega), using a Victor TM X3

400 multilabel reader (Perkin Elmer). Each serum sample was run in duplicate and was

401 measured against the four SARS-CoV-2 variants within the same experiment using the

402 same dilution series.

403

404 
medRxiv preprint doi: https://doi.org/10.1101/2021.06.07.21258351; this version posted June 8, 2021. The copyright holder for this preprint (which was not certified by peer review) is the author/funder, who has granted medRxiv a license to display the preprint in perpetuity.

It is made available under a CC-BY-NC-ND 4.0 International license .

\section{Acknowledgments:}

406 This work was funded by; King's Together Rapid COVID-19 Call awards to MHM, KJD and

407 SJDN, MRC Discovery Award MC/PC/15068 to SJDN, KJD and MHM, Fondation Dormeur,

408 Vaduz for funding equipment to KJD, Huo Family Foundation Award to MHM, KJD, MSH

409 and SJDN, MRC Genotype-to-Phenotype UK National Virology Consortium (MR/W005611/1

410 to MHM, KJD and SJDN), MRC Programme Grant (MR/S023747/1 to MHM), Wellcome

411 Trust Investigator Award 106223/Z/14/Z to MHM, NIAID Awards Al150472 and Al076119 to

412 MHM. MSH is funded by the National Institute for Health Research Clinician Scientist Award

413 (CS-2016-16-011). The views expressed in this publication are those of the author(s) and

414 not necessarily those of the NHS, the National Institute for Health Research or the

415 Department of Health and Social Care. CG, SH and HW were supported by the MRC-KCL

416 Doctoral Training Partnership in Biomedical Sciences (MR/N013700/1). SA was supported

417 by an MRC-KCL Doctoral Training Partnership in Biomedical Sciences industrial

418 Collaborative Award in Science \& Engineering (iCASE) in partnership with Orchard

419 Therapeutics (MR/R015643/1). NA is funded by the Wellcome Trust PhD program Cell

420 therapies and regenerative medicine (108874/Z/15/Z). This work was supported by the

421 Department of Health via a National Institute for Health Research comprehensive

422 Biomedical Research Centre award to Guy's and St. Thomas' NHS Foundation Trust in

423 partnership with King's College London and King's College Hospital NHS Foundation Trust.

424 This study is part of the EDCTP2 programme supported by the European Union (grant

425 number RIA2020EF-3008 COVAB). The views and opinions of authors expressed herein do

426 not necessarily state or reflect those of EDCTP.

428 Thank you to Florian Krammer for provision of the RBD expression plasmid, Philip Brouwer,

429 Marit van Gils and Rogier Sanders (University of Amsterdam) for the Spike protein construct,

430 Leo James and Jakub Luptak for the $\mathrm{N}$ protein, and James Voss and Deli Huang for

431 providing the Hela-ACE2 cells. 
medRxiv preprint doi: https://doi.org/10.1101/2021.06.07.21258351; this version posted June 8, 2021. The copyright holder for this preprint (which was not certified by peer review) is the author/funder, who has granted medRxiv a license to display the preprint in perpetuity.

It is made available under a CC-BY-NC-ND 4.0 International license .

\section{Figures:}

434 Figure 1: Serum Spike IgG binding and neutralizing activity is sustained up to 305

435 days POS. ELISA was used to assess the binding of $A$ ) $\lg M$ to Spike, B) $\lg M$ to $R B D, C$ )

$436 \lg M$ to $N, D) \lg G$ to $S, E) \lg G$ to $R B D$ and $F$ ) $\lg G$ to $N$. Sera was diluted to $1: 50$ and samples

437 were run in duplicate. The vertical dotted line indicates the time period that was studied in

438 our original analysis of this cohort. ${ }^{8}$ Each line represents one individual, and they are colour

439 coded as follows: red - severity $4-5$, black - severity 0-3 and green - healthcare workers. G)

440 Neutralization $\left(\mathrm{ID}_{50}\right)$ measured against HIV-1 pseudotyped virus particles expressing the

441 Wuhan Spike (wild-type, WT). The vertical dotted line indicates the latest timepoint studied

442 in our original analysis of this cohort. ${ }^{8} \mathrm{H}$ ) Comparison of the mean $\mathrm{ID}_{50}$ between individuals

443 experiencing 0-3 and 4-5 disease severity at different times post onset of symptoms (POS)

444 and for the highest neutralization titre measured (Peak). Severity $0-3$ is shown in black and

445 severity 4-5 is shown in red. $p$-values were calculated using a Mann-Whitney two-sided test

$446 U$-test. ns, not significant. The line represents the geometric mean $I D_{50}$ for each group.

A

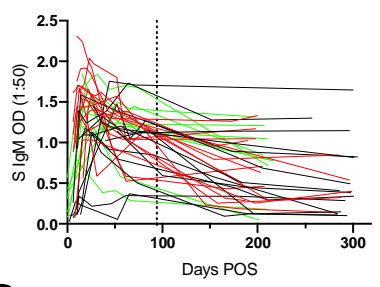

D

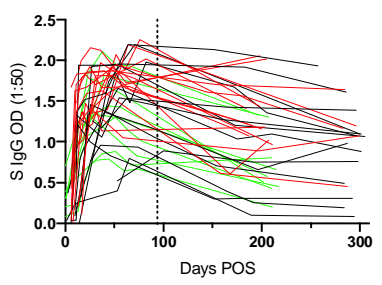

G

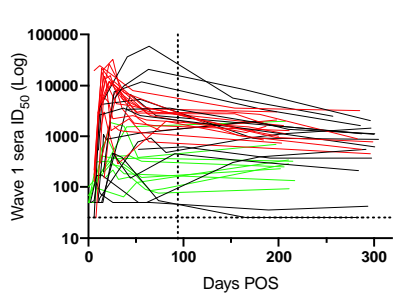

B

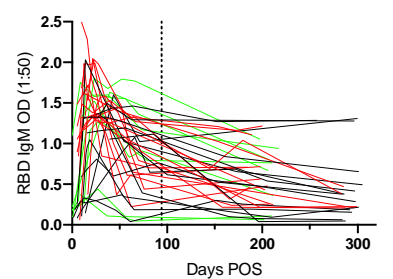

E
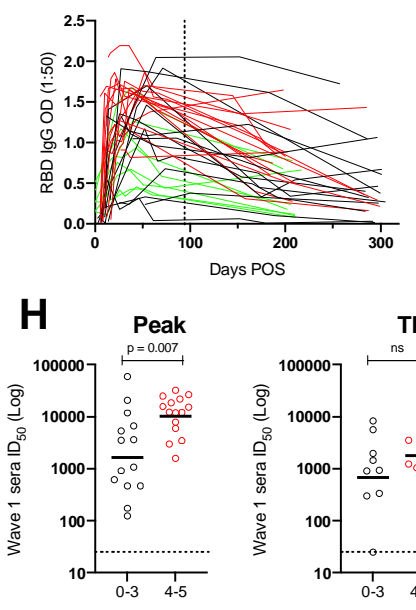

C

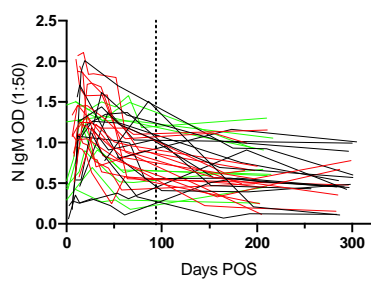

$\mathbf{F}$
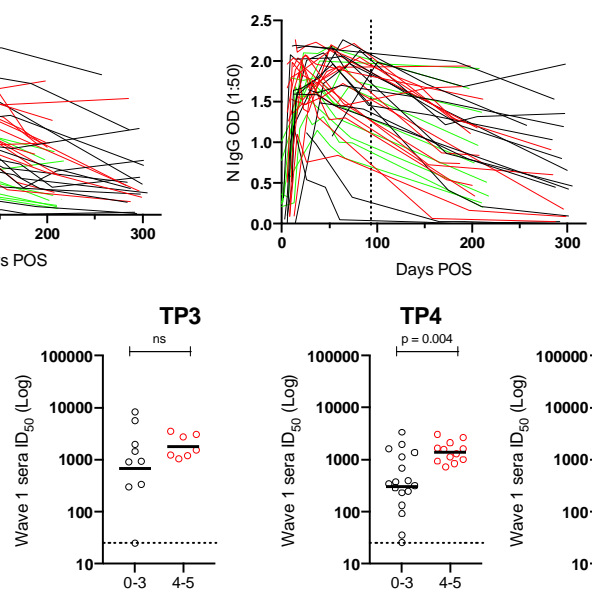

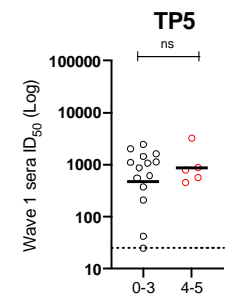


medRxiv preprint doi: https://doi.org/10.1101/2021.06.07.21258351; this version posted June 8, 2021. The copyright holder for this preprint (which was not certified by peer review) is the author/funder, who has granted medRxiv a license to display the preprint in perpetuity.

It is made available under a CC-BY-NC-ND 4.0 International license.

449 
medRxiv preprint doi: https://doi.org/10.1101/2021.06.07.21258351; this version posted June 8, 2021. The copyright holder for this preprint

(which was not certified by peer review) is the author/funder, who has granted medRxiv a license to display the preprint in perpetuity.

It is made available under a CC-BY-NC-ND 4.0 International license .

450 Figure 2: Sera from Wave 1 shows cross-neutralization of SARS-CoV-2 variants of

451 concern. A) Schematic showing the position of Spike mutations in B.1.1.7, P.1 and B.1.351.

452 The major Spike domains are indicated. B) Longitudinal neutralization by wave 1 sera

453 against WT, B.1.1.7, P.1 and B.1.351. Neutralization is shown for 14 individuals. C)

454 Neutralization of sera collected within five different time periods against the four SARS-CoV-

4552 variants. Geometric mean titres (GMT) against each virus are shown on each panel. Each

456 line represents one individual, and each individual is sampled $\leq 1$ at each timepoint. The

457 dotted lines represent the neutralization cut-offs used to determine no, low, medium, high

458 and potent neutralization (See Figures S1C). Red line represents the geometric mean titre

459 against that virus. D) Fold change in neutralization compared to WT pseudovirus at the five

460 timepoints. Black lines represent the average fold change. E) Comparison of the geometric

461 mean titre between those with $0-3$ (Black) and 4-5 (red) disease severity for the four

462 variants. All sera collected up to 305 days POS are included in this analysis $(n=107) . p$ -

463 values were calculated using a Mann-Whitney two-sided test $U$-test. ns, not significant. The

464 line represents the geometric mean $I_{50}$ for each group. 
medRxiv preprint doi: https://doi.org/10.1101/2021.06.07.21258351; this version posted June 8, 2021. The copyright holder for this preprint (which was not certified by peer review) is the author/funder, who has granted medRxiv a license to display the preprint in perpetuity.

It is made available under a CC-BY-NC-ND 4.0 International license .
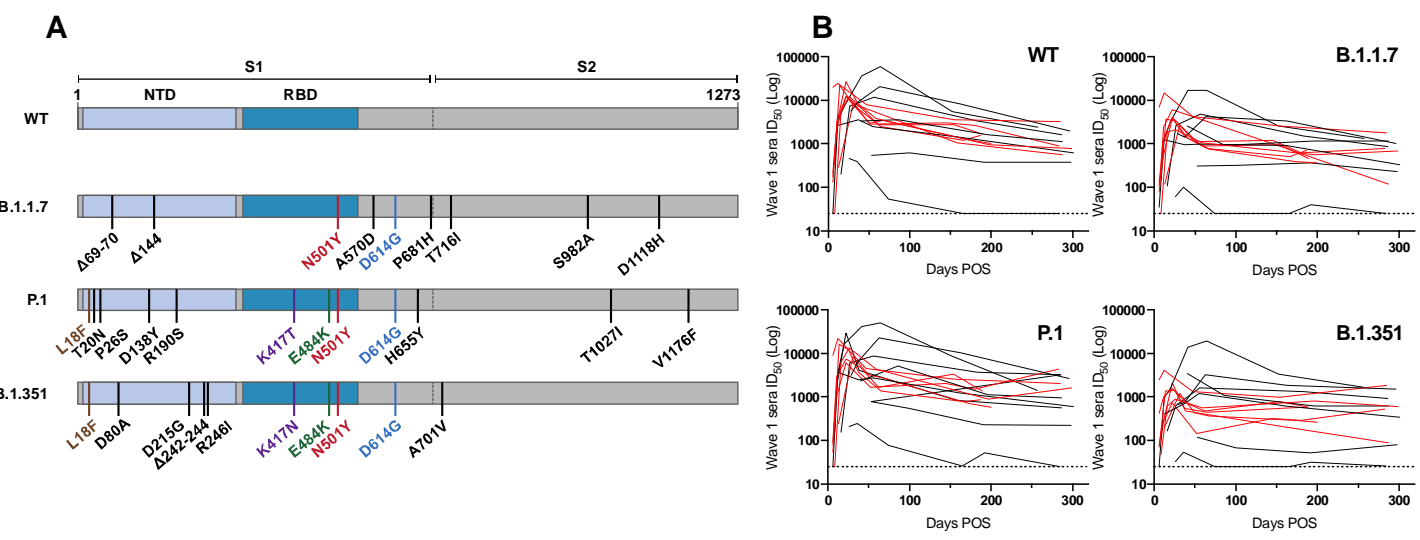

\section{C}

acute

TP2

TP3

TP4
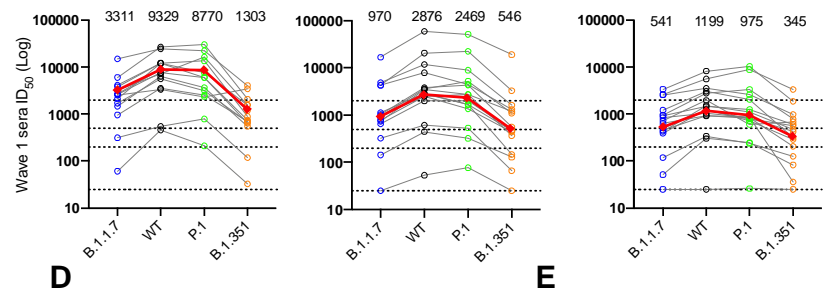

TP5

E
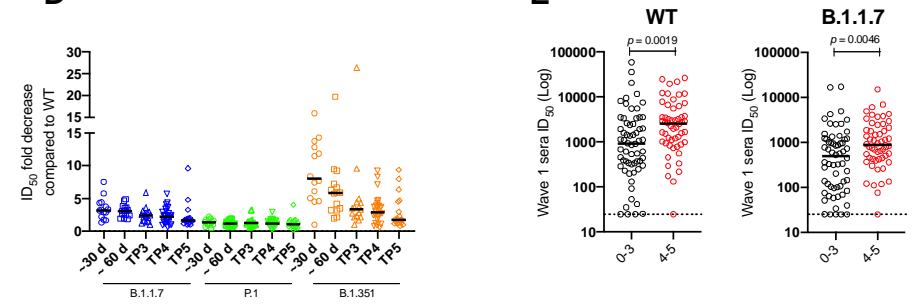

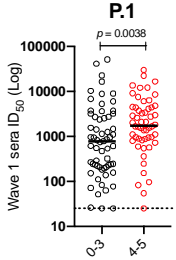

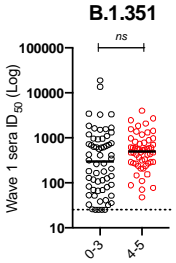

465

466 
medRxiv preprint doi: https://doi.org/10.1101/2021.06.07.21258351; this version posted June 8, 2021. The copyright holder for this preprint (which was not certified by peer review) is the author/funder, who has granted medRxiv a license to display the preprint in perpetuity.

It is made available under a CC-BY-NC-ND 4.0 International license .

467 Figure 3: Neutralizing antibody response in individuals infected with B.1.1.7. A) Serum

468 neutralization against B.1.1.7 at different time windows. Black line represents the geometric

469 mean titre. B) Neutralization of B.1.1.7 pseudovirus by sequential serum samples. Each line

470 represents samples from 1 donor across multiple timepoints. C) Comparison of homologous

471 neutralization (i.e. neutralization of WT pseudovirus by wave 1 sera and neutralization of

472 B.1.1.7 pseudovirus by sera from B.1.1.7 infected individuals) at peak neutralization (21-35

473 days POS). Line represents the geometric mean titre. $p$-values were calculated using a

474 Mann-Whitney two-sided test $U$-test. D) Cross-neutralizing activity of sera collected between

475 days 10-60 POS from individuals infected with B.1.1.7 against 4 SARS-CoV-2 variants $(n=$

476 74). Each line represents a serum sample. Red line represents the geometric mean titre

477 against that virus. E) Cross-neutralizing activity of sera collected between days 10-60 POS

478 from individuals infected in wave 1 against 4 SARS-CoV-2 variants $(n=35)$. Each line

479 represents a serum sample. Red line represents the geometric mean titre against that virus.

480 F) Comparison of the neutralization potency of B.1.1.7 sera against SARS-CoV-2 variants

481 between individuals experiencing disease severity 0-3 and 4-5. The black lines represent the

482 geometric mean titres. $p$-values were calculated using a Mann-Whitney two-sided test $U$ -

483 test. ns, not significant. G) Cross-neutralizing activity of sera collected from three individuals

484 infected with B.1.351. Sera were collected at two time points from two of these individuals

485 (between 26-52 days POS). Red line represents the geometric mean titre against that virus. 
medRxiv preprint doi: https://doi.org/10.1101/2021.06.07.21258351; this version posted June 8, 2021. The copyright holder for this preprint (which was not certified by peer review) is the author/funder, who has granted medRxiv a license to display the preprint in perpetuity.

It is made available under a CC-BY-NC-ND 4.0 International license .

A
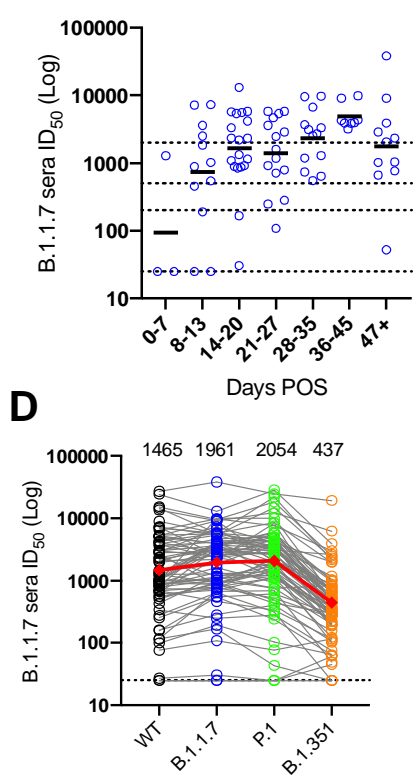

D Days POS
B

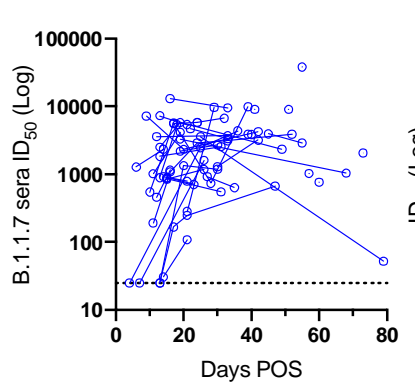

E

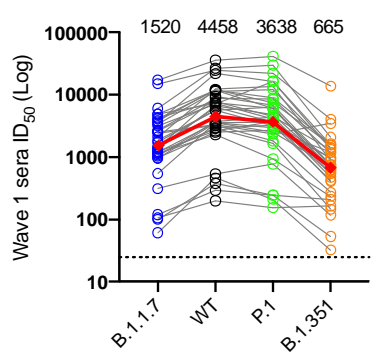

$\mathbf{F}$
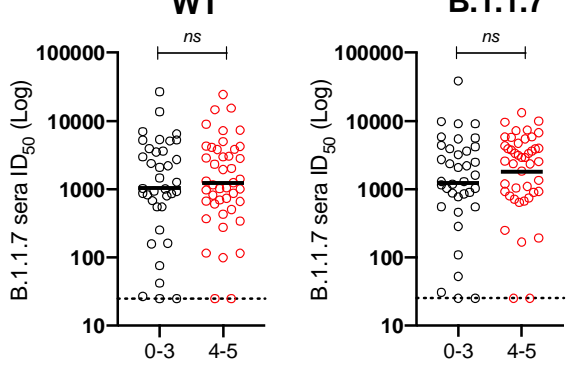

B.1.1.7

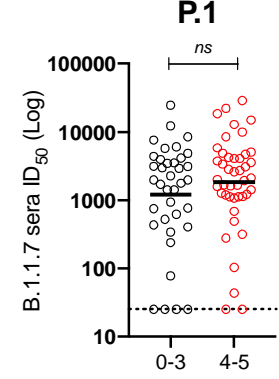

G

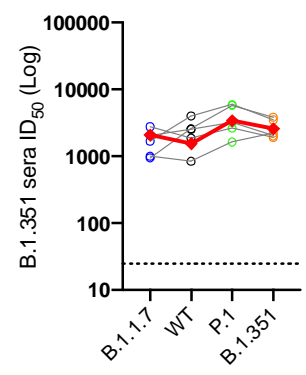

486

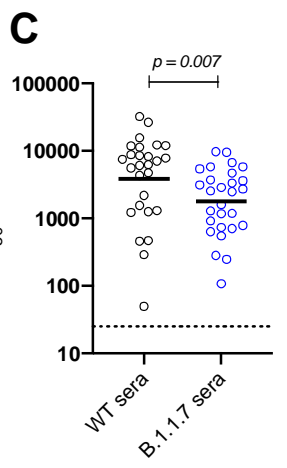

P.1

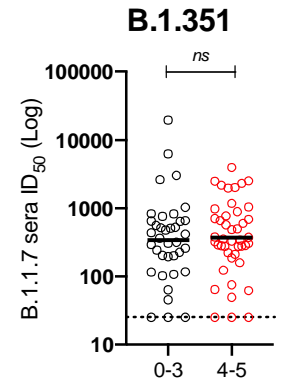


medRxiv preprint doi: https://doi.org/10.1101/2021.06.07.21258351; this version posted June 8, 2021. The copyright holder for this preprint

(which was not certified by peer review) is the author/funder, who has granted medRxiv a license to display the preprint in perpetuity.

It is made available under a CC-BY-NC-ND 4.0 International license.

489 Supplementary Figures:

490 Figure S1: Neutralizing antibodies persist for up to 10 months post onset of

491 symptoms. A) $I D_{50}$ of neutralization for all wave 1 sera included in Figure $1 \mathrm{G}$. B) Correlation

492 between $\mathrm{ID}_{50}$ (measured against pseudovirus) and either optimal density of IgG binding to $\mathrm{S}$,

493 RBD or $\mathrm{N} .\left(r^{2}=0.6942\right), \operatorname{RBD}\left(r^{2}=0.6250\right.$ and $\mathrm{N}$ protein $\left(r^{2}=0.3861\right)$ (Spearman's

494 correlation, $r$; a linear regression was used to calculate the goodness of fit, $r^{2}$ ). C)

495 Percentage of individuals in each time window with undetectable $\left(\mathrm{ID}_{50}<25\right)$, low $\left(\mathrm{ID}_{50} 25\right.$ -

496 200), medium (ID $50201-500)$, high (ID $501-2,000)$ or potent $\left(I_{50} 2,000+\right)$ neutralizing

497 antibody titres. The peak neutralization time point $(n=)$ includes hospitalized patients and

498 healthcare workers reported in Seow et $a l,{ }^{8}$ as well as 14 additional donors reported in this

499 study. The time point from the longitudinal samples with the peak $\mathrm{ID}_{50}$ was used in "peak".

500 TP3, TP4 and TP5 include serum samples collected between 145-175, 180-217 and 257-

501305 days POS. 
A

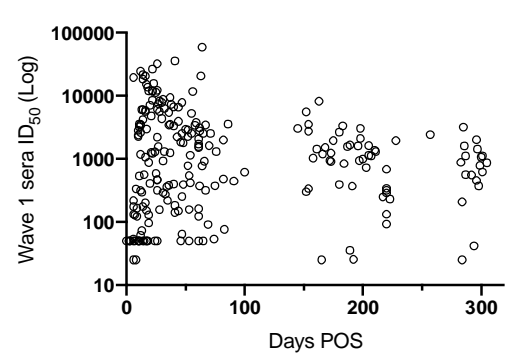

B
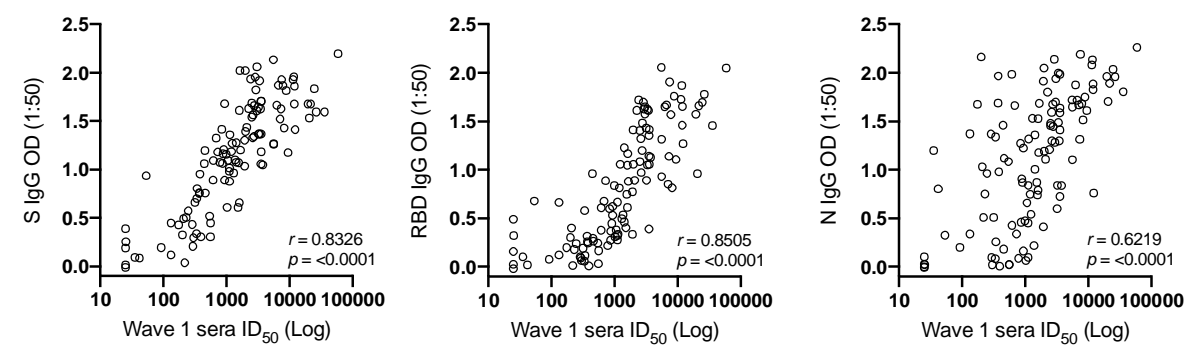

C

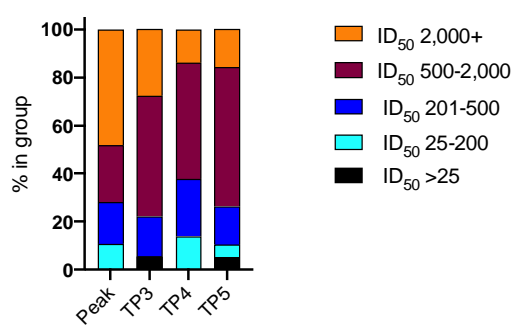

503 Figure S2: Cross-neutralizing antibody response in individuals infected with B.1.1.7.

504 A) Serum neutralization against WT, P.1 and B.1.351 at different time windows. Black line

505 represents the geometric mean titre. B) Neutralization of WT, P.1 and B.1.351 pseudovirus

506 by sequential serum samples. Each line represents samples from 1 donor across multiple

507 timepoints. C) Cross-neutralizing activity of sera from individuals infected with B.1.1.7

508 against 4 SARS-CoV-2 variants $(n=83)$. Each line represents a serum sample. Red line

509 represents the geometric mean titre against that virus. 
medRxiv preprint do: https://doi.org/10.1101/2021.06.07.21258351; this version posted June 8, 2021. The copyright holder for this preprint (which was not certified by peer review) is the author/funder, who has granted medRxiv a license to display the preprint in perpetuity. It is made available under a CC-BY-NC-ND 4.0 International license .

A

WT

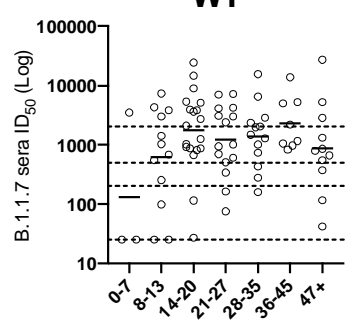

B
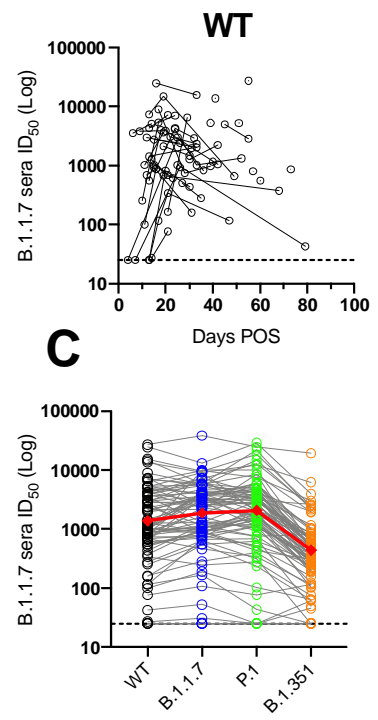

P.1

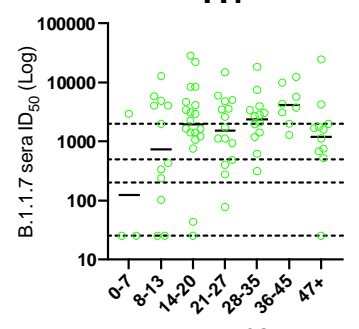

Days POS

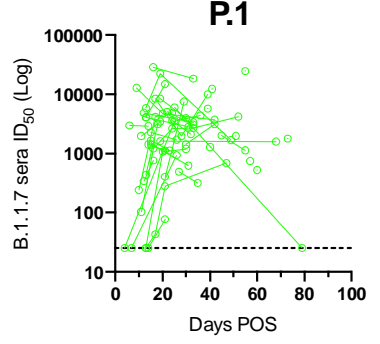

510

511

512

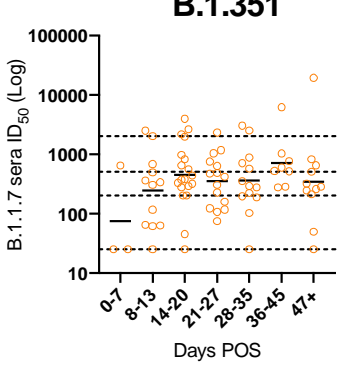

B.1.351

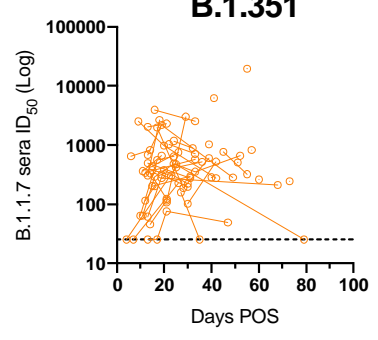

26 
medRxiv preprint doi: https://doi.org/10.1101/2021.06.07.21258351; this version posted June 8, 2021. The copyright holder for this preprint (which was not certified by peer review) is the author/funder, who has granted medRxiv a license to display the preprint in perpetuity. It is made available under a CC-BY-NC-ND 4.0 International license .

\section{References:}

5141 van Doremalen, N. et al. ChAdOx1 nCoV-19 vaccine prevents SARS-CoV-2 2608-y (2020).

2 Addetia, A. et al. Neutralizing Antibodies Correlate with Protection from SARS-CoV-2 in Humans during a Fishery Vessel Outbreak with a High Attack Rate. J Clin Microbiol 58, doi:10.1128/JCM.02107-20 (2020).

3 Cromer, D. et al. Prospects for durable immune control of SARS-CoV-2 and prevention of reinfection. Nat Rev Immunol, doi:10.1038/s41577-021-00550-x (2021).

4 Khoury, D. S. et al. Neutralizing antibody levels are highly predictive of immune protection from symptomatic SARS-CoV-2 infection. Nat Med, doi:10.1038/s41591021-01377-8 (2021).

5 Chandrashekar, A. et al. SARS-CoV-2 infection protects against rechallenge in rhesus macaques. Science 369, 812-817, doi:10.1126/science.abc4776 (2020).

6 McMahan, K. et al. Correlates of protection against SARS-CoV-2 in rhesus macaques. Nature 590, 630-634, doi:10.1038/s41586-020-03041-6 (2021).

7 Muecksch, F. et al. Longitudinal analysis of serology and neutralizing antibody levels in COVID19 convalescents. J Infect Dis, doi:10.1093/infdis/jiaa659 (2020).

8 Seow, J. et al. Longitudinal observation and decline of neutralizing antibody responses in the three months following SARS-CoV-2 infection in humans. Nat Microbiol 5, 1598-1607, doi:10.1038/s41564-020-00813-8 (2020).

9 Wajnberg, A. et al. Robust neutralizing antibodies to SARS-CoV-2 infection persist for months. Science 370, 1227-1230, doi:10.1126/science.abd7728 (2020).

10 Beaudoin-Bussieres, G. et al. Decline of Humoral Responses against SARS-CoV-2 Spike in Convalescent Individuals. mBio 11, doi:10.1128/mBio.02590-20 (2020).

11 Crawford, K. H. D. et al. Dynamics of neutralizing antibody titers in the months after SARS-CoV-2 infection. J Infect Dis, doi:10.1093/infdis/jiaa618 (2020).

12 Carvalho, T., Krammer, F. \& Iwasaki, A. The first 12 months of COVID-19: a timeline of immunological insights. Nat Rev Immunol 21, 245-256, doi:10.1038/s41577-02100522-1 (2021).

13 Rambaut, A. et al. Preliminary genomic characterisation of an emergent SARS-CoV2 lineage in the UK defined by a novel set of spike mutations. . (2020).

14 Tegally, H. et al. Sixteen novel lineages of SARS-CoV-2 in South Africa. Nat Med 27, 440-446, doi:10.1038/s41591-021-01255-3 (2021).

15 Davies, N. G. et al. Estimated transmissibility and impact of SARS-CoV-2 lineage B.1.1.7 in England. Science 372, doi:10.1126/science.abg3055 (2021).

16 Brown, J. C. \& al, e. Increased transmission of SARS-CoV-2 lineage B.1.1.7 (VOC $2020212 / 01$ ) is not accounted for by a replicative advantage in primary airway cells or antibody escape. bioRxiv, doi:10.1101/2021.02.24.432576 (2021).

17 Volz, E. \& al, e. Transmission of SARS-CoV-2 Lineage B.1.1.7 in England: Insights from linking epidemiological and genetic data. medRxiv, doi:10.1101/2020.12.30.20249034 (2021).

18 Piccoli, L. et al. Mapping Neutralizing and Immunodominant Sites on the SARS-CoV2 Spike Receptor-Binding Domain by Structure-Guided High-Resolution Serology. Cell 183, 1024-1042 e1021, doi:10.1016/j.cell.2020.09.037 (2020).

19 Garcia-Beltran, W. F. et al. Multiple SARS-CoV-2 variants escape neutralization by vaccine-induced humoral immunity. Cell, doi:10.1016/j.cell.2021.03.013 (2021).

20 Graham, C. et al. Neutralization potency of monoclonal antibodies recognizing dominant and subdominant epitopes on SARS-CoV-2 Spike is impacted by the B.1.1.7 variant. Immunity, doi:10.1016/j.immuni.2021.03.023 (2021).

21 Rees-Spear, C. et al. The effect of spike mutations on SARS-CoV-2 neutralization. Cell Rep, 108890, doi:10.1016/j.celrep.2021.108890 (2021).

566 vaccine-induced sera. Cell, doi:10.1016/j.cell.2021.02.037 (2021). 
medRxiv preprint doi: https://doi.org/10.1101/2021.06.07.21258351; this version posted June 8, 2021. The copyright holder for this preprint (which was not certified by peer review) is the author/funder, who has granted medRxiv a license to display the preprint in perpetuity. It is made available under a CC-BY-NC-ND 4.0 International license .

56723 Supasa, P. et al. Reduced neutralization of SARS-CoV-2 B.1.1.7 variant by 568 convalescent and vaccine sera. Cell 184, 2201-2211 e2207,

569

570

571

572

573

574

575

576

577

578

579

580

581

582

583

584

585

586

587

588

589

590

591

592

593

594

595

596

597

598

599

600

601

602

603

604

605

606

607

608

609

610

611

612

613

614

615

616

617

618

619

620 doi:10.1016/j.cell.2021.02.033 (2021).

24 Wang, P. et al. Antibody Resistance of SARS-CoV-2 Variants B.1.351 and B.1.1.7. Nature, doi:10.1038/s41586-021-03398-2 (2021).

25 Wibmer, C. K. et al. SARS-CoV-2 501Y.V2 escapes neutralization by South African COVID-19 donor plasma. Nat Med, doi:10.1038/s41591-021-01285-x (2021).

26 Cele, S. et al. Escape of SARS-CoV-2 501Y.V2 from neutralization by convalescent plasma. Nature 593, 142-146, doi:10.1038/s41586-021-03471-w (2021).

27 Chen, R. E. \& al, e. Resistance of SARS-CoV-2 variants to neutralization by monoclonal and serum-derived polyclonal antibodies. Nat Med, doi:doi.org/10.1038/s41591-021-01294-w (2021).

28 Wang, P. et al. Increased resistance of SARS-CoV-2 variant P.1 to antibody neutralization. Cell Host Microbe 29, 747-751 e744, doi:10.1016/j.chom.2021.04.007 (2021).

29 Planas, D. et al. Sensitivity of infectious SARS-CoV-2 B.1.1.7 and B.1.351 variants to neutralizing antibodies. Nat Med 27, 917-924, doi:10.1038/s41591-021-01318-5 (2021).

30 Collier, D. A. et al. Sensitivity of SARS-CoV-2 B.1.1.7 to mRNA vaccine-elicited antibodies. Nature, doi:10.1038/s41586-021-03412-7 (2021).

31 Kemp, S. A. et al. SARS-CoV-2 evolution during treatment of chronic infection. Nature, doi:10.1038/s41586-021-03291-y (2021).

32 McCarthy, K. R. et al. Recurrent deletions in the SARS-CoV-2 spike glycoprotein drive antibody escape. Science, doi:10.1126/science.abf6950 (2021).

33 Harvey, W. T. et al. SARS-CoV-2 variants, spike mutations and immune escape. Nat Rev Microbiol, doi:10.1038/s41579-021-00573-0 (2021).

34 Su, D. Broad neutralization against SARS-CoV-2 variants induced by a modified B.1.351 protein-based COVID-19 vaccine candidate. bioRxiv, doi:10.1101/2021.05.16.444369 (2021).

35 Callaway, E. Rare COVID reactions might hold key to variant-proof vaccines. Nature 592, 20-21, doi:10.1038/d41586-021-00722-8 (2021).

$36 \mathrm{Ji}, \mathrm{R}$. R. et al. BNT162b2 Vaccine Encoding the SARS-CoV-2 P2 S Protects Transgenic hACE2 Mice against COVID-19. Vaccines (Basel) 9, doi:10.3390/vaccines9040324 (2021).

$37 \mathrm{Wu}, \mathrm{K}$. et al. Variant SARS-CoV-2 mRNA vaccines confer broad neutralization as primary or booster series in mice. bioRxiv, doi:10.1101/2021.04.13.439482 (2021).

38 Faulkner, N. \& al, e. Reduced antibody cross-reactivity following infection with B.1.1.7 than with parental SARS-CoV-2 strains. bioRxiv, doi:10.1101/2021.03.01.433314 (2021).

39 Moyo-Gwete, T. et al. Cross-Reactive Neutralizing Antibody Responses Elicited by SARS-CoV-2 501Y.V2 (B.1.351). N Engl J Med, doi:10.1056/NEJMc2104192 (2021).

40 Pickering, S. et al. Comparative assessment of multiple COVID-19 serological technologies supports continued evaluation of point-of-care lateral flow assays in hospital and community healthcare settings. PLoS Pathog 16, e1008817, doi:10.1371/journal.ppat.1008817 (2020).

41 Monin, L. et al. Safety and immunogenicity of one versus two doses of the COVID-19 vaccine BNT162b2 for patients with cancer: interim analysis of a prospective observational study. Lancet Oncol, doi:10.1016/S1470-2045(21)00213-8 (2021).

42 Parry, H. F. \& al, e. Extended interval BNT162b2 vaccination enhances peak antibody generation in older people. medRxiv, doi:10.1101/2021.05.15.21257017 (2021).

43 Callow, K. A., Parry, H. F., Sergeant, M. \& Tyrrell, D. A. The time course of the immune response to experimental coronavirus infection of man. Epidemiol Infect 105, 435-446, doi:10.1017/s0950268800048019 (1990). 
62144 Edridge, A. W. D. et al. Seasonal coronavirus protective immunity is short-lasting.

622

623

624

625

626

627

628

629

630

631

632

633

634

635

636

637

638

639

640

641

642

643

644

645

646

647

648

649

650

651

652

653

654

655

656

657

658

659

660

661

662

663

664

665

666

667

668

669

670

671

672

673

674

675

Nat Med 26, 1691-1693, doi:10.1038/s41591-020-1083-1 (2020).

$45 \mathrm{Wu}, \mathrm{J}$. et al. SARS-CoV-2 infection induces sustained humoral immune responses in convalescent patients following symptomatic COVID-19. Nat Commun 12, 1813, doi:10.1038/s41467-021-22034-1 (2021).

46 Yamayoshi, S. et al. Antibody titers against SARS-CoV-2 decline, but do not disappear for several months. EClinicalMedicine 32, 100734, doi:10.1016/j.eclinm.2021.100734 (2021).

47 Dan, J. M. et al. Immunological memory to SARS-CoV-2 assessed for up to 8 months after infection. Science 371, doi:10.1126/science.abf4063 (2021).

48 Anand, S. P. et al. Longitudinal analysis of humoral immunity against SARS-CoV-2 Spike in convalescent individuals up to 8 months post-symptom onset. bioRxiv, doi:10.1101/2021.01.25.428097 (2021).

49 Wheatley, A. K. et al. Evolution of immune responses to SARS-CoV-2 in mildmoderate COVID-19. Nat Commun 12, 1162, doi:10.1038/s41467-021-21444-5 (2021).

50 Vanshylla, K. et al. Kinetics and correlates of the neutralizing antibody response to SARS-CoV-2 infection in humans. Cell Host Microbe, doi:10.1016/j.chom.2021.04.015 (2021).

51 Cohen, K. W. et al. Longitudinal analysis shows durable and broad immune memory after SARS-CoV-2 infection with persisting antibody responses and memory B and T cells. medRxiv, doi:10.1101/2021.04.19.21255739 (2021).

52 Anand, S. P. et al. Longitudinal analysis of humoral immunity against SARS-CoV-2 Spike in convalescent individuals up to eight months post-symptom onset. Cell Rep Med, 100290, doi:10.1016/j.xcrm.2021.100290 (2021).

53 Gasser, R. et al. Major role of IgM in the neutralizing activity of convalescent plasma against SARS-CoV-2. Cell Rep 34, 108790, doi:10.1016/j.celrep.2021.108790 (2021).

54 Turner, J. S. et al. SARS-CoV-2 infection induces long-lived bone marrow plasma cells in humans. Nature, doi:10.1038/s41586-021-03647-4 (2021).

55 Gaebler, C. et al. Evolution of antibody immunity to SARS-CoV-2. Nature 591, 639644, doi:10.1038/s41586-021-03207-w (2021).

56 Weisblum, Y. et al. Escape from neutralizing antibodies by SARS-CoV-2 spike protein variants. Elife 9, doi:10.7554/eLife.61312 (2020).

57 Greaney, A. J. et al. Comprehensive mapping of mutations in the SARS-CoV-2 receptor-binding domain that affect recognition by polyclonal human plasma antibodies. Cell Host Microbe, doi:10.1016/j.chom.2021.02.003 (2021).

58 Starr, T. N. et al. Prospective mapping of viral mutations that escape antibodies used to treat COVID-19. Science, doi:10.1126/science.abf9302 (2021).

59 McCallum, M. et al. N-terminal domain antigenic mapping reveals a site of vulnerability for SARS-CoV-2. Cell, doi:10.1016/j.cell.2021.03.028 (2021).

60 Fischer, R. J. et al. ChAdOx1 nCoV-19 (AZD1222) protects hamsters against SARSCoV-2 B.1.351 and B.1.1.7 disease. bioRxiv, doi:10.1101/2021.03.11.435000 (2021).

61 Madhi, S. A. et al. Efficacy of the ChAdOx1 nCoV-19 Covid-19 Vaccine against the B.1.351 Variant. N Engl J Med, doi:10.1056/NEJMoa2102214 (2021).

62 Shinde, V. et al. Efficacy of NVX-CoV2373 Covid-19 Vaccine against the B.1.351 Variant. N Engl J Med, doi:10.1056/NEJMoa2103055 (2021).

63 Munitz, A., Yechezkel, M., Dickstein, Y., Yamin, D. \& Gerlic, M. BNT162b2 Vaccination Effectively Prevents the Rapid Rise of SARS-CoV-2 Variant B.1.1.7 in high risk populations in Israel. Cell Rep Med, 100264, doi:10.1016/j.xcrm.2021.100264 (2021).

64 Emary, K. R. W. et al. Efficacy of ChAdOx1 nCoV-19 (AZD1222) vaccine against SARS-CoV-2 variant of concern 202012/01 (B.1.1.7): an exploratory analysis of a randomised controlled trial. Lancet 397, 1351-1362, doi:10.1016/S01406736(21)00628-0 (2021). 
medRxiv preprint doi: https://doi.org/10.1101/2021.06.07.21258351; this version posted June 8, 2021. The copyright holder for this preprint (which was not certified by peer review) is the author/funder, who has granted medRxiv a license to display the preprint in perpetuity.

It is made available under a CC-BY-NC-ND 4.0 International license .

67665 Guthmiller, J. J. et al. SARS-CoV-2 Infection Severity Is Linked to Superior Humoral

677

678

679

680

681

682

683

684

685

686

687

688

689

690

691

692

66 Legros, V. et al. A longitudinal study of SARS-CoV-2-infected patients reveals a high correlation between neutralizing antibodies and COVID-19 severity. Cell Mol Immunol, doi:10.1038/s41423-020-00588-2 (2021).

67 Zohar, T. et al. Compromised Humoral Functional Evolution Tracks with SARS-CoV2 Mortality. Cell 183, 1508-1519 e1512, doi:10.1016/j.cell.2020.10.052 (2020).

68 ARTICnetwork, <https://artic.network/ncov-2019> (2021).

69 O'Toole, A. et al. pangolin: lineage assignment in an emerging pandemic as an epidemiological tool, <https://github.com/cov-lineages/pangolin> (2021).

70 Grehan, K., Ferrara, F. \& Temperton, N. An optimised method for the production of MERS-CoV spike expressing viral pseudotypes. MethodsX 2, 379-384, doi:10.1016/j.mex.2015.09.003 (2015).

71 Thompson, C. P. et al. Detection of neutralising antibodies to SARS-CoV-2 to determine population exposure in Scottish blood donors between March and May 2020. Euro Surveill 25, doi:10.2807/1560-7917.ES.2020.25.42.2000685 (2020). 